\title{
Embryonic and Larval Development of Silver Barb (Barbodes gonionotus) in a Mobile Hatchery under Laboratory Condition
}

\author{
${ }^{1}$ Siddhwartha Kumar Basak, ${ }^{2}$ Biplob Basak, ${ }^{3}$ Nipa Gupta, ${ }^{2}$ S.M. Mustafizur \\ Rahman, ${ }^{2}$ Dr. Mohammad Mahfujul Haque \\ ${ }^{I}$ Department of Aquaculture, Bangladesh Agricultural University, Mymensingh, Bangladesh and WorldFish, \\ Dhaka, Bangladesh \\ ${ }^{2}$ Department of Aquaculture, Bangladesh Agricultural University, Mymensingh, Bangladesh \\ ${ }^{3}$ Department of Aquaculture, Hajee Mohammad Danesh Science and Technology University, Dinajpur, \\ Bangladesh
}

\begin{abstract}
This investigation was carried out for 14 days to determine different developmental stages of embryo and larvae with special emphasis on time requirement for progress of the stages. For breeding of silver barb, $P G$ was injected as an inducing agent for ovulation of eggs inside the ovary however; external stripping was applied to ejaculate the eggs. Sophisticated digital camera (Olympus $C \times 41)$ connected with a laptop was used for intensive observation on the developmental stages in the close proximity of Low Cost Mobile Hatchery $(L C M H)$. Well fertilized eggs were transformed into fry through different stages of embryonic development, hatchlings to larvae and then fry completing several morphological and physiological changes. The size of fertilized and unfertilized eggs was $0.8 \pm 0.05$ and $0.7 \pm 0.05 \mathrm{~mm}$, respectively. Initial 4 stages from fertilized egg to blastula was quicker being completed within 5 hrs compared to following 4 stages from gastrula to hatchling that took 9 hrs. This indicates quality hatchlings production within a limited time having an importance in hatchery management system. During the larval development stages, yolk sac was absorbed within 72 hrs indicating proper time of first external feeding. The alimentary canal and conversion of notochord to vertebra through segmentation occurred within 144 and $192 \mathrm{hrs}$ respectively. However, final development of pectoral, pelvic, caudal and dorsal fins with rays, mouth and scale formation were completed within 336 hrs after hatchling stage.
\end{abstract}

Keywords: Embryonic development, Larvae, Barbodes gonionotus, Bangladesh.

\section{Introduction}

Among exotic species, the silver barb (B. gonionotus), is an indigenous food fish of Thailand where it is locally known as Thai silver barb. It was introduced into Bangladesh in 1987 to augment fish production through incorporation into our carp polyculture system. Its ability to thrive well in stressed conditions coupled with its fast growth rate and taste has made it a popular culturable species in Bangladesh. It grows fast at high stocking density [Karim et al., 1988] and this omnivorous fish feeds mainly on soft aquatic weeds, grasses, algae, and zooplankton, insect larvae and annelids. This fish grows to table fish size within three to four months [Gupta and Rab 1994]. It normally breeds in streams, rivers and its spawning season varies from March to June. However, induced breeding and larval rearing techniques are not well adopted by the fish farmers of Bangladesh [Chakraborty et al., 2006].

The environment of Bangladesh is very much suitable for culture of silver barb. It can be cultured in any types of water body such as ponds, beels, rivers, canals and recently rice field during boro and amon season. It can raise 150-170 g within short culture period (5-6 months) [Hussain et al., (eds.) 2008].

Having several advantages of silver barb culture, a great prospect remains to culture this fish in our country but the fry availability is not sufficient to meet the requirement. Sometimes, it is quite impossible to supply the fry to the fish farmer during the culture period started. Seed production at the farmer's level when supply available then it is possible to involve a wide range of farmers to culture this fish in the remote areas. As a part of farmers' friendly approach, a Low Cost Mobile Hatchery is expected to solve those problems. By establishing this hatchery in remote area, any poor and marginal fish farmers can produce fry which can be cultured in their ponds. After fertilization of eggs, it goes on several stages up to the fingerlings. Every stage is very much sensitive and critical. During this period, any deviation from a smooth operating system mass mortality may occur. Therefore, larval development studies are essential because to save a life, to reduce the mortality rate of fry, to manage the surrounding environment of larvae and also to know the relationships between environment and larvae. Otherwise, there is no way to overcome this problem. Considering the enormous importance of silver barb, the present study was carried out to study the early life history stages at 
different time interval, to identify different developmental stages of larvae, and to identify the first feeding time which may be of great help to the farmers involving into the culture of silver barb.

\subsection{Research Site and facilities development}

\section{Materials and Methods}

The embryonic and larval development of silver barb (B. gonionotus) was studied at the Low Cost Mobile Hatchery (LCMH), designed and constructed in the laboratory of the Department of Aquaculture, Faculty of Fisheries, Bangladesh Agricultural University (BAU), Mymensingh, Bangladesh during February 2010 to August 2010 [Basak 2010].

Ten brood fishes of silver barb were collected from Bangladesh Fisheries Research Institute (BFRI), Mymensingh, Bangladesh. The collected brood fishes were stocked in the previously prepared cistern. Induced breeding and hatching were carried out in the LCMH under laboratory condition. Based on the physical and visual examination of secondary sexual characteristics by observing abdomen and genital opening, the ripe male (6) and female (4) brood fishes were selected for induce breeding at a ratio of 1.5:1. The average weight of the selected males and females were $155 \pm 5 \mathrm{~g}$ and $160 \pm 5 \mathrm{~g}$, respectively.

\subsection{Induced breeding of fish}

After selection of brood fishes, mature males and females were acclimatized for about 6-8 hrs. Gentle water flow using shower was provided to induce the breeding condition and to ensure proper aeration. Conditioning was necessary to prepare the brood fish for inducing programme by ensuring the empty gut. Locally available processed carp pituitary glands were used as inducing agent and the required amount was weighed with the analytical electronic balance. The amount weighed was calculated based on the body weight of brood fishes using the following formula:

$$
\text { Weight of PG }(\mathrm{g})=\frac{\mathrm{W}_{\mathrm{t}} \times \mathrm{P}_{\mathrm{t}}}{1000}
$$

Here, $\mathrm{W}_{\mathrm{t}}$ represents total body weight $(\mathrm{g})$ of brood fishes and $\mathrm{P}_{\mathrm{t}}$ represents the weight $(\mathrm{mg})$ of $\mathrm{PG}$ to be injected/kg body weight.

In this experiment, the PG was injected at a dose of $6 \mathrm{mg} / \mathrm{Kg}$ body weight for female, of which $4 \mathrm{mg} / \mathrm{Kg}$ body weight as first dose and $2 \mathrm{mg} / \mathrm{Kg}$ body weight was second dose after $6 \mathrm{hrs}$ of first dose. During second dose of female, the male was induced for only once by PG at $3 \mathrm{mg} / \mathrm{Kg}$ body weight. After 5-6 hrs of PG injection, the ovulation was done by stripping in plastic small bowl. The milt was added to eggs immediately and mixed by poultry feather for a period of 60 seconds for proper fertilization and then water was added and placed in a bottle jar. A continuous flow of water was maintained. The hatchlings came out after 13.40-14.00 hrs of fertilization which was kept in the hatching jar for three days without feeding. After three days, the hatchlings were transferred to circular tank and maintained gentle circulation of water for proper larval development.

\subsection{Observation in larval development}

The egg samples were collected randomly from the bottle jars for observing the embryonic developmental stages of B. gonionotus at every 15,30, $45 \mathrm{~min}$. and $1 \mathrm{hr}$ interval till completion of cleavage, morula, gastrula and hatching stages, respectively. The egg samples were taken on slide with little distilled water for clear observation of the embryonic developmental stages. Hard boiled chicken egg yolk and finely ground wheat flour was mixed with small amount of water thoroughly and sieved by a plastic glass fiber net. Then this fine and very small particulate emulsion was used to feed larvae just after yolk sac absorption as first feeding four times daily. The observation was started just after fertilization and continued for 14 days up to the end point of larval developmental stages. The early developmental stages were observed by a microscope (Olympus $\mathrm{C} \times 41$ ) with digital camera (Magnus analytics, Model-MIPS) and their images were taken by laptop (Acer Brand) connected with a USB data cable.

\section{Results}

This study was performed to find out the developmental clock of B. gonionotus for early developmental stages. A short description of embryonic and larval development with relation to the time is presented in Table 1 and 2.

\subsection{Stages during the embryonic and zygote period}

Unfertilized eggs (0h): The unfertilized eggs of B. gonionotus were spherical in shape and brownish in color. The eggs were highly laden with yolk, which remains at the vegetal pole. Eggs measured $0.7 \pm 0.05 \mathrm{~mm}$ in diameter (Fig. 1A). 
Fertilized eggs: Immediately after fertilization the diameter of the egg was $0.8 \pm 0.05 \mathrm{~mm}$ (Fig. 1B). A fertilized egg is called a zygote. At this stage it consists of a nucleus, cytoplasm (all parts other than the nucleus) and external membrane then cells divided rapidly. The fertilized eggs were found adhesive, sticky, demersal and slight brownish in color.

One cell stage $(\mathbf{0 . 1 5}$ h): Fertilization also activated cytoplasmic movements, easily evident within about 15 minutes. No yolky cytoplasm began to stream toward the animal pole, segregating the blastodisc from the clearer yolk granule-rich vegetal cytoplasm (Fig. 1C). Eggs were measured $1.0 \pm 0.05 \mathrm{~mm}$ in diameter.

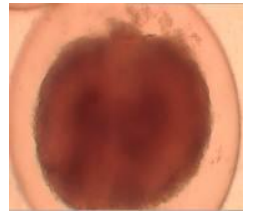

A. Unfertilized egg

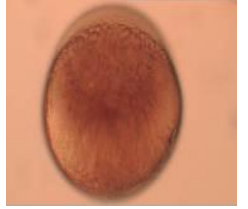

B. Fertilized egg

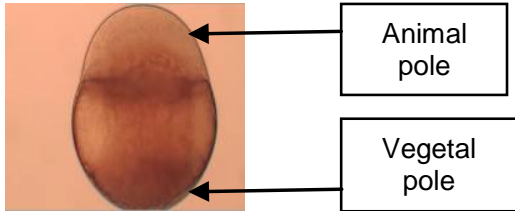

C. 1-cell stage

Fig. 1. Developmental stages in zygote period.

\subsection{Stages during the cleavage period}

Two cell stage $-\mathbf{1}^{\text {st }}$ cleavage $(\mathbf{0 . 3 5} \mathbf{~ h r})$ : The first cleavage of eggs occurred within 35 minutes after fertilization. The furrow arose near the animal pole and progressed rapidly toward the vegetal pole, passing only through the blastodisc but not the yolky region of the egg. The blastodisc was divided into 2 distinct equal size cells by vertical cleavage (Fig. 2A). Eggs were measured $1.1 \pm 0.05 \mathrm{~mm}$ in diameter.

Four cell stage- $2^{\text {nd }}$ cleavage $(0.50$ hr): Four cells stage was observed within 50 minutes. Hence, cycle 3 begins with four blastomeres in a $2 \times 2$ array. The diameter of the egg was $1.3 \pm 0.05 \mathrm{~mm}$ (Fig. 2B).

Eight cell stage- $3^{\text {rd }}$ cleavage $(\mathbf{1 . 0 0} \mathbf{~ h r})$ : This stage was observed within $1.00 \mathrm{hr}$. Cleavages ending cycle 3 , still incomplete, occur in two separate planes, parallel to the first one, and on either side of it. They cut the blastodisc into a $2 \times 4$ array of blastomeres (Fig. 2C). The diameter of the egg was $1.5 \pm 0.05 \mathrm{~mm}$.

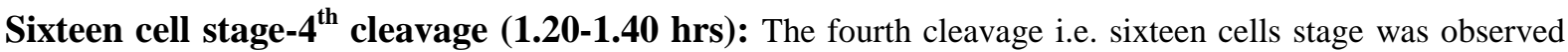
within 1.20-1.40 hrs. The egg diameter was $1.7 \pm 0.05 \mathrm{~mm}$ (Fig. 2D). The fourth set of cleavages also occurred along two planes, parallel to and on either side of the second one, and produces $4 \times 4$ array of cells.

Thirty-two cell stage $-5^{\text {th }}$ cleavage $(\mathbf{2 . 0 0} \mathbf{~ h r s})$ : The thirty-two cell stage was observed within $2.00 \mathrm{hrs}$. Frequently the 32 blastomeres of this stage were present in $4 \times 8$ array. The egg diameter was $1.8 \pm 0.05 \mathrm{~mm}$ (Fig. 2E).

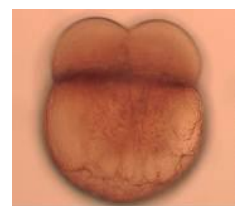

A. 2-cell

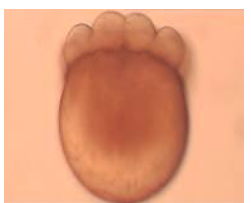

B. 4-cell

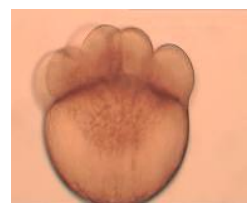

C. 8-cell

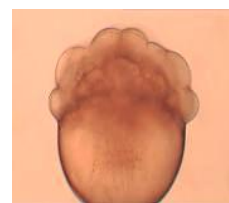

D. 16-cell

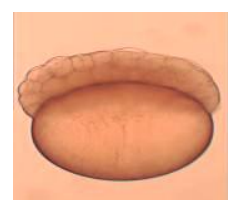

E. 32-cell

Fig. 2. Developmental stages at cleavage stage.

\subsection{Stages during the morula period}

Early morula-64 cell stage (2.20-2.30 hrs): The blastomeres were decreased in size and the morula stage was reached between 2.20-2.30 hrs. At this stage the crown of the blastoderm started to cover about the yolk in the form of a thin layer. Eggs were measured $2.0 \pm 0.05 \mathrm{~mm}$ in diameter (Fig. 3A).

Late morula-128-256 cell stage (3.00-3.30 hrs): The blastodermal cells (128-256 blastomeres) were smaller than those of the previous stage and the number of marginal cells was increased. This stage called late morula stage was observed between 3.00-3.30 hrs. The egg diameter was $2.1 \pm 0.05 \mathrm{~mm}$ (Fig. 3B-C).

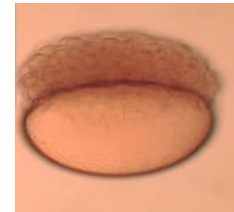

A. 64-cell stage

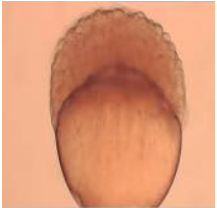

B. 128-cell stage

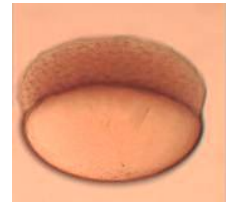

C. 256-cell stage

Fig. 3. Developmental stages at morula stage 


\subsection{Stages during the blastula period}

High stage (4.00 hrs): The blastoderm was still high (thick) as in the late morula stage, although its inner cells were smaller. The blastodisc was migrated in the direction of the vegetal pole to envelop the major part of the yolk. The egg diameter was $2.1 \pm 0.05 \mathrm{~mm}$ (Fig. 4A). This stage was observed within $4.00 \mathrm{hrs}$.

Sphere stage $(4.20 \mathrm{hrs})$ : Continued shortening along the animal-vegetal axis and approximately spherical shape. In this stage some blastomeres was begun to cleave asynchronously and to migrate several rows of periblast nuclei were visible around the blastoderm. The egg diameter was $2.2 \pm 0.05 \mathrm{~mm}$ (Fig. 4B). This stage was recorded within $4.20 \mathrm{hrs}$.

Dome formation (4.35-4.45 hrs): This stage was recorded within 4.35-4.45 hrs. The blastoderm was flattened down onto the yolk sphere resulting a dome shape structure (Fig. 4C). The egg diameter was observed at $2.3 \pm 0.05 \mathrm{~mm}$. This prominent and rapidly occurring change in the interface between the yolk cell and the blastodisc represented the first sure sign that epiboly was began. In this stage, the cell layers were slightly thicker on one side.

30\%-epiboly formation (5.00 hrs): Epiboly, including doming of the yolk cell, produced a blastoderm, nearly uniform thickness. The embryonic shield was arisen as a thickened margin of the blastoderm at $30 \%$ of the entire distance between the animal and vegetal poles (Fig. 4D). The egg diameter was observed at $2.3 \pm 0.05$ $\mathrm{mm}$. This stage was recorded within $5.00 \mathrm{hrs}$.

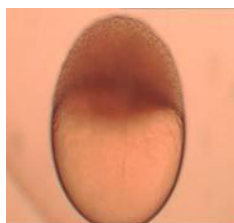

A. High stage

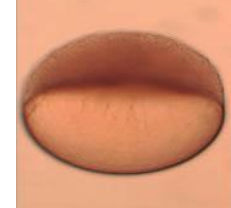

B. Sphere stage

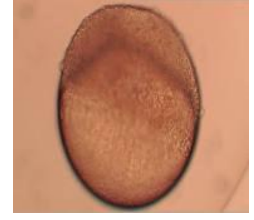

C. Dome formation

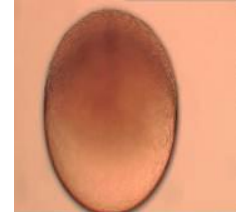

D. 30\%-epiboly

Fig. 4. Developmental stages during blastula period.

\subsection{Stages during the gastrula period}

50\%-epiboly stage (5.20 hrs): Epiboly displaced the blastoderm margin to 50\% of the distance between the animal and vegetal pole (Fig. 5A). At this 50\%-epiboly stage radial intercalations have produced a blastoderm that was very uniform in thickness. The egg diameter was $2.4 \pm 0.05 \mathrm{~mm}$ at $28.0^{\circ} \mathrm{C}$. This stage was recorded within 5.20 hrs.

Germ ring formation $(5.30 \mathrm{hrs})$ : The germ ring appeared nearly uniform in structure around the entire circumference of the blastoderm. The yolk cell remained about half covered by the blastoderm (Fig. 5B). The middle of the embryonic shield projecting into the germ ring area. It was measured $2.4 \pm 0.05 \mathrm{~mm}$. This stage was observed within $5.30 \mathrm{hrs}$.

Shield stage (6.00 hrs): The embryonic shield became more clearly visible as a narrow steak. An animal polar view most easily revealed the embryonic shield, as well as the germ ring. Epiboly exists at $50 \%$ until late shield stage, when the yolk cell could be judged to be more than half covered by the blastoderm (Fig. 5C). It was measured $2.4 \pm 0.05 \mathrm{~mm}$. This stage was observed within $6.00 \mathrm{hrs}$.

75\%-epiboly stage (6.15-6.25 hrs): As epiboly continued the shape of the embryo itself became more along the animal-vegetal axis (Fig. 5D). A side view showed that the blastoderm was thinner than elsewhere on the ventral side, above the margin. This stage was observed within 6.15-6.25 hrs. The egg diameter was $2.5 \pm 0.05 \mathrm{~mm}$.

90\%-epiboly stage $(6.30 \mathrm{hrs})$ : This stage was observed within $6.30 \mathrm{hrs}$. In this stage, the yolk sphere was nearly covered (90\% of the yolk) by thin blastoderm leaving small area around the vegetal pole (yolk plug) exposed (Fig. 5E). The earliest post-mitotic cells were present, including cells that will form the notochord, axial somite-derived muscles and specific neurons in the hindbrain. The egg diameter was $2.5 \pm 0.05 \mathrm{~mm}$.

Bud formation (6.40 hrs): Epiboly came to a close as the blastoderm completely covered the yolk plug, defining 100\%-epiboly. The brain and nerve cord was developed as a solid rod of cells in this stage. Along the dorsal side, anterior to the tail bud, the neural plate is now thickened along the entire embryonic axis; its more posterior cells would contribute to trunk spinal cord (Fig. $5 \mathrm{~F}$ ). The egg diameter was $2.5 \pm 0.05 \mathrm{~mm}$ at $28.5^{\circ} \mathrm{C}$. This stage was observed within $6.40 \mathrm{hrs}$. 


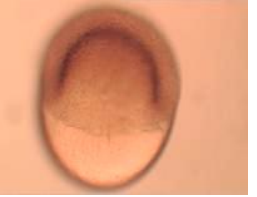

A. 50\%-epiboly

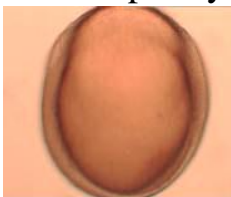

D. $75 \%$-epiboly

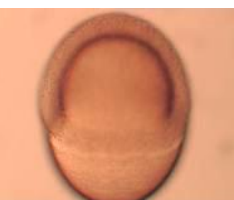

B. Germ ring

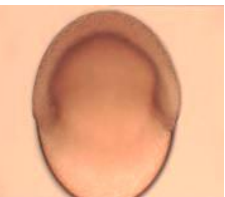

C. Shield stage

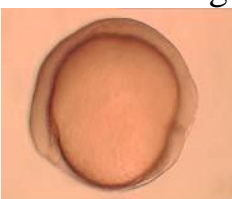

Fig. 5. Developmental stages in gastrula period.

Table 1. Summary of embryonic development process of initial 4 stages of B. gonionotus

\begin{tabular}{|c|c|c|c|c|c|c|}
\hline Period (hrs) & Stage & Figure & $\begin{array}{l}\text { Time after } \\
\text { fertilization } \\
\text { (hrs) }\end{array}$ & $\begin{array}{l}\text { Mean } \\
\text { temperature } \\
\left({ }^{\circ} \mathbf{C}\right)\end{array}$ & $\begin{array}{l}\text { Mean egg } \\
\text { diameter } \\
( \pm)(\mathbf{m m})\end{array}$ & Progress in embryonic development \\
\hline $\begin{array}{l}\text { Zygote }(0.00- \\
0.35)\end{array}$ & 1 -cell & $1 \mathrm{C}$ & 0.15 & 29.0 & $1.0 \pm 0.05$ & $\begin{array}{l}\text { Non-yolky cytoplasm toward the animal } \\
\text { pole, segregating the blastodisc from the } \\
\text { clearer yolk }\end{array}$ \\
\hline \multirow{5}{*}{$\begin{array}{l}\text { Cleavage } \\
(0.35-2.00)\end{array}$} & 2-cell & $2 \mathrm{~A}$ & 0.35 & 28.5 & $1.1 \pm 0.05$ & Partial cleavage \\
\hline & 4-cell & 2B & 0.50 & 28.5 & $1.3 \pm 0.05$ & $2 \times 2$ array of blastomeres \\
\hline & 8-cell & $2 \mathrm{C}$ & 1.00 & 29.0 & $1.5 \pm 0.05$ & $2 \times 4$ array of blastomeres \\
\hline & 16-cell & $2 \mathrm{D}$ & $1.20-1.40$ & 29.0 & $1.7 \pm 0.05$ & $4 \times 4$ array of blastomeres \\
\hline & 32-cell & $2 \mathrm{E}$ & 2.00 & 29.0 & $1.8 \pm 0.05$ & $4 \times 8$ array of blastomeres \\
\hline \multirow{4}{*}{$\begin{array}{l}\text { Morula } \\
(2.00-3.30)\end{array}$} & 64-cell & $3 \mathrm{~A}$ & $2.20-2.30$ & 28.0 & $2.0 \pm 0.05$ & 3 regular tiers of blastomeres \\
\hline & $\begin{array}{l}128-256 \\
\text { cell }\end{array}$ & $3 \mathrm{~B}-\mathrm{C}$ & $3.00-3.30$ & 28.0 & $2.1 \pm 0.05$ & $\begin{array}{l}\text { 5-7 blastomere tiers; } \\
\text { cleavage planes irregular }\end{array}$ \\
\hline & High & $4 \mathrm{~A}$ & 4.00 & 28.5 & $2.1 \pm 0.05$ & 7 blastomere tiers \\
\hline & Sphere & $4 \mathrm{~B}$ & 4.20 & 28.5 & $2.2 \pm 0.05$ & $\begin{array}{l}\text { Spherical shape; flat border between } \\
\text { blastodisc and yolk }\end{array}$ \\
\hline \multirow[t]{2}{*}{$\begin{array}{l}\text { Blastula } \\
(3.30-5.00)\end{array}$} & Dome & $4 \mathrm{C}$ & $4.35-4.45$ & 28.0 & $2.3 \pm 0.05$ & $\begin{array}{l}\text { Shape remains spherical; yolk cell } \\
\text { bulging (doming) toward animal pole as } \\
\text { epiboly begins }\end{array}$ \\
\hline & $\begin{array}{l}30 \%- \\
\text { Epiboly }\end{array}$ & 4D & 5.00 & 28.0 & $2.3 \pm 0.05$ & $\begin{array}{l}\text { Blastoderm an inverted cup of uniform } \\
\text { thickness }\end{array}$ \\
\hline
\end{tabular}

Table 2. Summary of embryonic development process of last 4 stages of $B$. gonionotus

\begin{tabular}{|l|l|l|l|l|l|l|}
\hline Period (hrs) & Stage & Figure & $\begin{array}{l}\text { Time after } \\
\text { fertilization } \\
(\mathrm{hrs})\end{array}$ & $\begin{array}{l}\text { Mean tempe- } \\
\text { rature } \\
\left({ }^{\circ} \mathrm{C}\right)\end{array}$ & $\begin{array}{l}\text { Mean egg } \\
\text { diameter } \\
( \pm)(\mathrm{mm})\end{array}$ & Progress in embryonic development \\
\hline \multirow{5}{*}{$\begin{array}{l}\text { Gastrula } \\
(5.00-6.40)\end{array}$} & $\begin{array}{l}50 \%- \\
\text { Epiboly }\end{array}$ & $5 \mathrm{~A}$ & 5.20 & 28.0 & $2.4 \pm 0.05$ & Blastoderm remains uniform in thickness \\
\cline { 2 - 7 } & Germ ring & $5 \mathrm{~B}$ & 5.30 & 27.5 & $2.4 \pm 0.05$ & Germ ring visible from animal pole \\
\cline { 2 - 7 } & Shield & $5 \mathrm{C}$ & 6.00 & 27.5 & $2.4 \pm 0.05$ & $\begin{array}{l}\text { Embryonic shield visible from animal } \\
\text { pole, 50\%-epiboly }\end{array}$ \\
\cline { 2 - 7 } & $\begin{array}{l}75 \%- \\
\text { epiboly }\end{array}$ & $5 \mathrm{D}$ & $6.15-6.25$ & 28.0 & $2.5 \pm 0.05$ & $\begin{array}{l}\text { Dorsal side distinctly thicker; epiblast, } \\
\text { hypoblast }\end{array}$ \\
\cline { 2 - 7 } & \begin{tabular}{l} 
epiboly \\
\cline { 2 - 6 }
\end{tabular} & $5 \mathrm{E}$ & 6.30 & 28.0 & $2.5 \pm 0.05$ & $\begin{array}{l}\text { Brain rudiment thickened; notochord } \\
\text { rudiment distinct from segmental plate }\end{array}$ \\
\cline { 2 - 7 } & Bud & $5 \mathrm{~F}$ & 6.40 & 28.5 & $2.5 \pm 0.05$ & $\begin{array}{l}\text { Tail bud prominent; notochord rudiment } \\
\text { distinct from neural keel; 100\%-epiboly }\end{array}$ \\
\hline
\end{tabular}


Embryonic and Larval Development of Silver Barb (Barbodes gonionotus) in a Mobile Hatchery

\begin{tabular}{|c|c|c|c|c|c|c|}
\hline \multirow{4}{*}{$\begin{array}{l}\text { Segmenta- } \\
\text { tion } \\
(6.40-10.00)\end{array}$} & $\begin{array}{l}5-9 \\
\text { somite }\end{array}$ & $6 \mathrm{~B}-\mathrm{C}$ & 7.30 & 28.5 & $2.6 \pm 0.05$ & $\begin{array}{l}\text { Brain and vesicle formation, appearance } \\
\text { of heart tubular }\end{array}$ \\
\hline & $\begin{array}{l}10-14 \\
\text { somite }\end{array}$ & 6D-E & $8.15-8.30$ & 29.0 & $2.7 \pm 0.05$ & $\begin{array}{l}\text { Tail rudiment begins subdivisions of the } \\
\text { brain spherical optic lenses }\end{array}$ \\
\hline & $\begin{array}{l}15-19 \\
\text { somite }\end{array}$ & $6 \mathrm{~F}$ & $8.30-8.50$ & 29.0 & $2.7 \pm 0.05$ & $\begin{array}{l}\text { Vitello-caudal vein were still } \\
\text { incomplete, blood was pumped from the } \\
\text { heart }\end{array}$ \\
\hline & $\begin{array}{l}20+ \\
\text { Somite }\end{array}$ & $6 \mathrm{G}$ & $9.30-10.00$ & 29.5 & $2.8 \pm 0.05$ & $\begin{array}{l}\text { Start of heart beating, pectoral fin buds, } \\
\text { otocysts and gill rudiment }\end{array}$ \\
\hline \multirow{4}{*}{$\begin{array}{l}\text { Pharyngula } \\
(10.00-13.10)\end{array}$} & Prim-5 & $7 \mathrm{~A}$ & $11.00-11.15$ & 29.5 & $2.9 \pm 0.05$ & $\begin{array}{l}\text { Heart is visible as a cone- shaped, } \\
\text { pericardial sac, notochord was } \\
\text { completely to the end of } \\
\text { the tail }\end{array}$ \\
\hline & Prim-15 & $7 \mathrm{~B}$ & $11.45-12.00$ & 29.5 & $2.9 \pm 0.05$ & $\begin{array}{l}\text { Blood circulation pectoral, pelvic fins, } \\
\text { head and the viscera duct }\end{array}$ \\
\hline & Prim-25 & $7 \mathrm{C}$ & $12.30-12.45$ & 30.0 & $3.0 \pm 0.05$ & $\begin{array}{l}\text { The development of heart and formation } \\
\text { of the pericardial cavity }\end{array}$ \\
\hline & High-pec & $7 \mathrm{D}$ & $13.00-13.10$ & 30.0 & $3.0 \pm 0.05$ & $\begin{array}{l}\text { Spleen was recognized. Developed } \\
\text { caudal fin rays, gall bladder. Both eyes } \\
\text { were moved actively at same time along } \\
\text { with movement of mouth and pectoral } \\
\text { fins }\end{array}$ \\
\hline $\begin{array}{l}\text { Hatchling } \\
(13.10-14.00)\end{array}$ & Long-pec & 8 & $13.40-14.00$ & 30.5 & $3.1 \pm 0.05$ & $\begin{array}{l}\text { Hatchling was started. Twisting } \\
\text { movement and separated from the yolk } \\
\text { mass. The embryos ruptured the egg } \\
\text { shell by the continuous movement }\end{array}$ \\
\hline
\end{tabular}

\subsection{Stages during the segmentation period}

One-two somite stage (7.00 hrs): The first somatic furrow formed usually after both completion of epiboly and the initial appearance of the tail bud (Fig. 6A). This furrow marked the boundary between what would become the first and second somites. The egg diameter was $2.6 \pm 0.05 \mathrm{~mm}$. This stage was observed within 7.00 hrs.

Five-nine somite stage (7.30 hrs): These stages were recorded within $7.30 \mathrm{hrs.}$ The brain primordium has now distinctively thickened into the neural keel and beginning at the five-nine somite stage one can first distinguish the optic primordium from a side view. In nine somatic stages, tubular heart was appeared underneath the head from the posterior end of the mid-brain to the anterior end of the hind-brain (Fig. 6B-C). Neural keel formation occurred in the anterior trunk between the six-nine somite stages. The egg diameter was $2.6 \pm 0.05 \mathrm{~mm}$.

Ten-fourteen somite stage (8.15-8.30 hrs): In 12 somite stage, a pair of semi-circular blood vessels and the vitello-caudal vein were begun to form on the yolk sphere. At the end of these stages, spherical optic lenses were prominent (Fig. 6D-E). These stages were observed within $8.15-8.30 \mathrm{hrs}$. It was measured $2.7 \pm 0.05 \mathrm{~mm}$.

Fifteen-nineteen somite stage (8.30-8.50 hrs): Semi-circular blood vessels and vitello-caudal vein were still incomplete at the beginning of the stage. Blood circulation began and blood was pumped from the heart. In 19 somite stage, the tail bud now began to protrude away from the body of the embryo (Fig. 6F). It was measured $2.7 \pm 0.05 \mathrm{~mm}$. This stage was seen within $8.30-8.50 \mathrm{hrs}$.

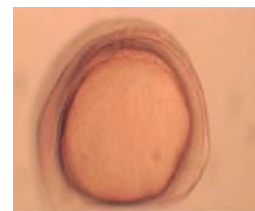

A. 2-somite stage

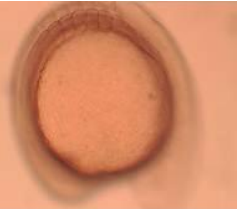

B. 6-somite stage

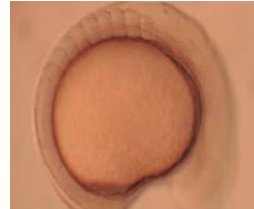

C. 8-somite stage

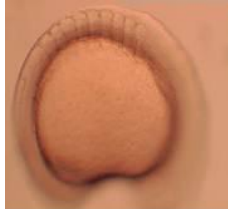

D. 10-somite stage 


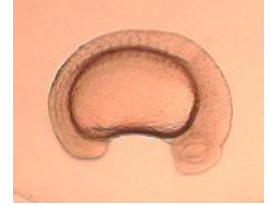

E. 14-somite stage

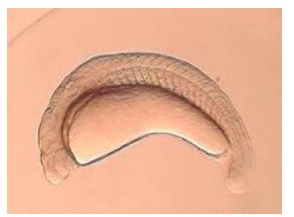

F. 18-somite stage

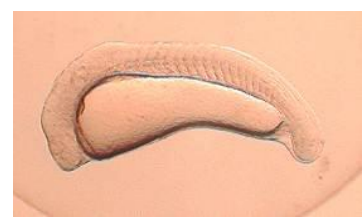

G. 25-somite stage

Fig. 6. Developmental stages in segmentation period

Above 20-somite stage (9.30-10.00 hrs): Pectoral fin was appeared and membranous fins were also seen in the tail region. The head and tail end of the embryo were differentiated. The beating heart was visible. Pectoral fin buds, otocysts and gill rudiment appeared one by one (Fig. 6G). Blood circulation was seen in the gill arches. It was measured $2.8 \pm 0.05 \mathrm{~mm}$. This stage was seen within $9.30-10.00 \mathrm{hrs}$.

\subsection{Stages during the pharyngula period}

Prim-5 stage (11.00-11.15 hrs): At the prim-5 stage, the heart was visible as a cone-shaped tube deep to the brain, seemingly more dorsal than its later location and prominently occupying a pericardial sac on the anterior region of the yolk. Distinct kidneys were laid in contact with bilateral sides of the notochord in the first somite. Notochord was completely reached the end of the tail (Fig. 7A). This stage was observed within 11.00-11.15 hrs. It was measured $2.9 \pm 0.05 \mathrm{~mm}$.

Prim-15 stage (11.45-12.00 hrs): The caudal fin had several melanophores and developed the eye. Blood circulation was appeared in pectoral and pelvic fins, which was frequently moved. Blood circulation was begun through the internal tissues of the head and the viscera duct (Fig.7B). It was measured $2.9 \pm 0.05 \mathrm{~mm}$.

Prim-25 stage (12.30-12.45 hrs): These stages were recorded within 12.30-12.45 hrs. It was measured $3.0 \pm 0.05 \mathrm{~mm}$. At this stage, the development of heart and formation of the pericardial cavity occurred. Pericardial cavity (cardiac sac) surrounding the heart was easily observed (Fig. 7C).

High-pec stage (13.00-13.10 hrs): At the high-pec stage, the spleen was recognized as a small reddish globule and the tail was extended beyond the otic vesicle and the rudiments of the caudal fin rays could be seen within the round membranous. A large well-developed gall bladder could be identified by its yellow or yellowish brown tint. Both eyes were moved actively at same time along with movement of mouth and pectoral fins (Fig. 7D). These stages were recorded within 13.00-13.10 hrs. It was measured $3.0 \pm 0.05 \mathrm{~mm}$.

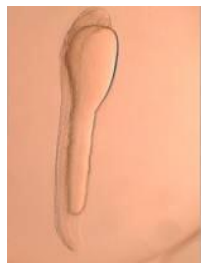

A. Prim-5 stage

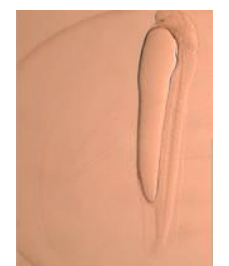

B. Prim-15 stage

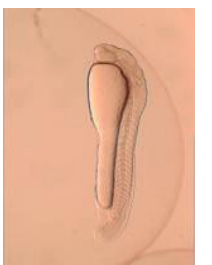

C. Prim- 25 stage

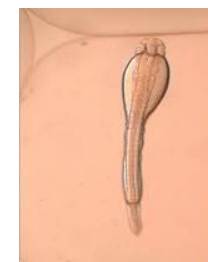

D. High-pec stage

Fig. 7. Developmental stages in pharyngula period.

\subsection{Stage during the hatchling period}

Hatching was started from 13.40 and completed within $14.00 \mathrm{hrs}$ after fertilization. This stage is called long-pec stage. In this stage, the tail gradually becomes separated from the yolk mass. Embryo started occasional twisting movement. The pectoral fin buds were quite elongated. The vigorous beat of the heart was easily showed. The embryo ruptured the egg shell by the continuous movement. After hatching, the internal wall of the swim bladder was expanded remarkably and then cells of the hatching gland had disappeared. The heart was prominent, beating strongly and full of circulating blood (Fig. 8). It was measured $3.1 \pm 0.05 \mathrm{~mm}$.

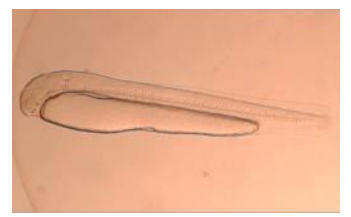

Fig. 8. Long- pec stage in hatching period. 


\subsection{Larval and post larval development}

The monitoring of larval development process of B. gonionotus at different stages was given below:

Newly post hatching larvae (14.00 hrs): Newly hatched larvae were slender, transparent, straight and tapering to the tail. At this stage of development they have no swim bladder, mouth opening or vent. They breathe by absorbing oxygen through the fine blood capillaries that surround the yolk sac, which were still attached to the gut (Fig. 9A). The mean length of hatchling was $2.2 \pm 0.05 \mathrm{~mm}$.

Six hours old larvae (20.00 hrs): Melanophores were prominent on head. The brain was clearly visible. Prominent notochord was found. Two chromatophores were present on the front side of the body (Fig. 9B). Optic lobe was slightly formed. The length of larvae measured averagely $2.5 \pm 0.05 \mathrm{~mm}$.

Twelve hours old larvae $\mathbf{( 2 6 . 0 0}$ hrs): Vertical melanophore bands became very prominent. Chromatophores were seen in the eye only and increased in number. The pectoral fin bud and mouth cleft had formed. Some melanophore observed on the head region (Fig. 9C). The average length of larvae was measured to be $2.9 \pm 0.05 \mathrm{~mm}$.

One day old larvae (38.00 hrs): After one day, the hatchlings showed free movement and operculum appeared but did not extend over gills. Dark eyes pigmented and myomeres were partially visible. Pectoral, anal fold and air bladder were become prominent and also distinct. The supply of yolk was diminished gradually and the snout was protruded in front of the yolk mass (Fig. 9D). At this stage, the average length of the larvae was $3.2 \pm 0.05 \mathrm{~mm}$.

Two days old larvae (62.00 hrs): Opercula fold was appeared at this stage. The yolk sac was gradually reduced at the anterior region. A few black chromatophores were visible of the caudal fin. The nearly alimentary canal was distinct. The brain formation was completed. The heartbeat was at the rate of $145-150 / \mathrm{min}$. At the end of the second day mouth was fully formed. The alimentary canal became well develops. Air bladder was round, small and silvery white in color. Pelvic fin was visible (Fig. 9E). At this stage, the average length of the larvae was $3.4 \pm 0.05 \mathrm{~mm}$.

Three days old larvae (86.00 hrs): At this stage, the average length of the larvae was $3.6 \pm 0.05 \mathrm{~mm}$. After 3 days of hatching, the yolk sac was completely absorbed and the larvae started exogenous feeding and was fed with supplementary feed of previously prepare egg yolk emulsion as first feeding. The mouth gap was quite large. The larva was silver-blackish in color (Fig. 9F).

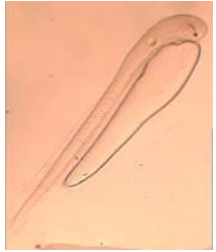

A. Zero hr

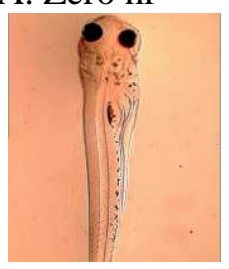

D. One-day

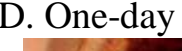

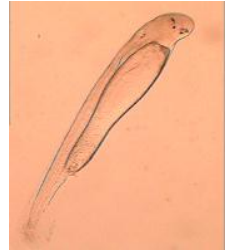

B. 6-hrs

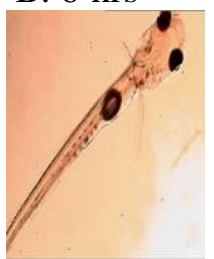

E. Two-days

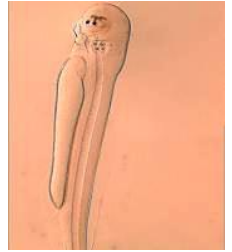

C. 12-hrs

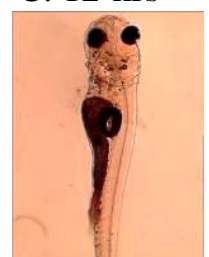

F. Three-day
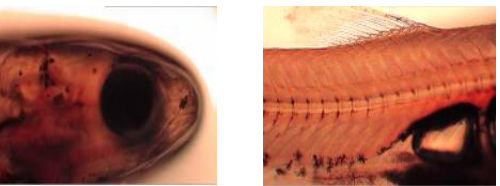

II) Mid region

J. Fourteen-days
I) Head region
G. Six-days

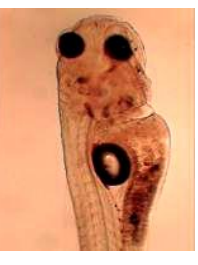

H. Eight-days

I. Ten-days

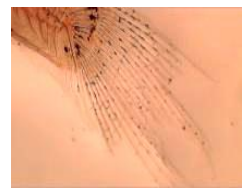

III) Tail region

Fig.9. Developmental stages in larval period of $B$. gonionotus.

Six days old larvae (158.00 hrs): At this stage, the average length of the larvae was $4.1 \pm 0.05 \mathrm{~mm}$. The alimentary canal was developed with a prominent rectum and well-defined anus (Fig. 9G). Caudal fin was being developed with 10-14 fin rays and pectoral fins were not well developed. 
Eight days old larvae (206.00 hrs): The eight days old larvae were $4.6 \pm 0.05 \mathrm{~mm}$ in length. (Fig. $9 \mathrm{H}$ ). Dorsal fin was not clear fin rays but visible. Large number of chromatophores was present on the caudal fin, head and body. Segmentation was appeared on the notochord i.e. future vertebra.

Ten days old larvae (254.00 hrs): The ten days old post larvae were measured $6.3 \pm 0.05 \mathrm{~mm}$ in length. Caudal fin was developed with 15-20 fin rays and dorsal fin with 4-6 fin rays. At this stage, scales were started appearing on the body and the larva loosed its transparency. Chromatophores were accumulated dense on the whole body (Fig. 9I). The pelvic and pectoral fins were become elongated.

Fourteen days old larvae $(\mathbf{3 5 0 . 0 0} \mathbf{~ h r s})$ : At this stage, the length of the fry ranged between $8-10 \mathrm{~mm}$ in length and they gradually resembled the adults in external features. According as they grew they developed paired fins, mouth and other organs. The young silver barb swim up to the surface and took two or three gulps of air, which they forced into their swim bladder. The scales were fully formed on the belly but incompletely towards the end of the tail and head. The caudal fin was well developed with 24-28 fin rays. The dorsal fin was well developed with 12-14 fin rays. The anal fin was developed with 6-9 fin rays (Fig. 9J).

\section{Discussion}

In the present study, it is reported the embryonic and larval development of B. gonionotus was observed in captivity. It was successful in obtaining the larvae of silver barb by artificial fertilization. The fertilized eggs were round, transparent, demersal and adhesive. The color of the fertilized eggs was slight brownish. Average diameter of fertilized eggs of silver barb was $0.8 \pm 0.05 \mathrm{~mm}$ and $0.7 \pm 0.05 \mathrm{~mm}$ of unfertilized eggs which was more or less similar to the finding of Chakraborty, 2004 who noted that the average diameter of fertilized and unfertilized eggs of $P$. sarana was same in color and $0.6 \pm 0.01 \mathrm{~mm}$ in diameter, respectively. However, Karim (2009) found $0.6 \pm 0.01 \mathrm{~mm}$ for Anabas testudineus and the color was brownish-yellow. This slight variation was possibly due to species variation. It was found that the average diameter of eggs immediately after fertilization was increased from $0.7 \pm 0.05$ to $0.8 \pm 0.05 \mathrm{~mm}$. While according to Chakraborty (2004), the diameter of eggs of $P$. sarana was increased from $0.6 \pm 0.01$ to $0.8 \pm 0.01 \mathrm{~mm}$, whereas Chakraborty and Murty (1972) reported that the diameter of eggs of L. rohita ranged between 4.1 to $4.8 \mathrm{~mm}$ with an average $4.4 \mathrm{~mm}$.

The two-cell stage, four-cell stage, eight-cell stage and sixteen-cell stage and multiple (64) cell stage of B. gonionotus were observed within $0.35,0.50,1.00,1.20-1.40,2.20-2.30 \mathrm{hrs}$ after fertilization, respectively where Chakraborty (2004), were found within $0.35,0.45,1.10,1.35,2.15 \mathrm{hrs}$ after fertilization, respectively in case of $P$. sarana which has similarity with the finding of the present experiment. Mookerjee (1945) also found the similar results in the case of L. rohita. Morula stage was found 2.0-3.3 hrs after fertilization. According to Chakraborty (2004) observed the same stage at $4 \mathrm{hrs}$ after fertilization in the case of $P$. sarana, whereas Mookerjee (1945) observed the same stage at $5.45 \mathrm{hrs}$ after fertilization in the case of $L$. rohita. This variation was due to the temperature and species. The gastrula stage was found in B. gonionotus 5.00 to $6.40 \mathrm{hrs}$ after fertilization at a water temperature of $28.0^{\circ} \mathrm{C}$. Chakraborty (2004) observed gastrulation at 8.0 to $10.40 \mathrm{hrs}$ after fertilization of egg at the temperature of $27.0 \pm 0.02^{\circ} \mathrm{C}$ in $P$. sarana.

The present study revealed that heart beat was observed at 9.30-10.00 hrs after fertilization, whereas Chakraborty (2004) observed the same at $14.00-15.30 \mathrm{hrs}$ in case of $P$. sarana. In the present experiment, optic bud and pericardial cavity formation were observed at 6.40 and 12.30-12.45 hrs after fertilization, respectively. Whereas Galman and Avtalion (1989) observed the same stage at 52 and $65 \mathrm{hrs}$ in the case of $O$. niloticus. This variation might be due to the species differences.

The hatching period in B. gonionotus was found from 13.20 to $14.00 \mathrm{hrs}$ after fertilization at a water temperature of $30.5^{\circ} \mathrm{C}$. Chakraborty (2004) observed that the hatching period in P. sarana at 18.00 to $20.00 \mathrm{hrs}$ after fertilization. The development of embryo and hatching time in fertilized egg of most of the fishes are generally influenced by the temperature of water [Jhingran, 1983]. This variation might be due to the species difference.

The length of the newly hatched larvae of B. gonionotus was found to be $2.2 \pm 0.05 \mathrm{~mm}$. But Chakraborty [2004] found that the length of newly hatched larvae of $P$. sarana to be $2.4 \pm 0.05 \mathrm{~mm}$ which has close similarity with the present findings. In larval stage, after hatching the development of pectoral fin bud of B. gonionotus appeared at $12 \mathrm{hrs}$ which was similar to P. sarana [Chakraborty, 2004] and Cirrhinus mrigala [Khan, 1943]. At larval stage, operculum appeared $24 \mathrm{hrs}$ after hatching but did not extend over gills, pectoral fin was prominent and air bladder was visible which were similar to P. sarana [Chakraborty, 2004] and Cirrhinus mrigala [Khan, 1943]. The yolk sac of the silver barb was completely disappeared $72 \mathrm{hrs}$ after hatching at a water temperature of $30.5^{\circ} \mathrm{C}$, whereas Chakraborty [2004] found these developments in P. sarana within 66 hrs and Chakraborty and Murty [1972] found same developments in C. mrigala within $72 \mathrm{hrs}$ which has the similarity with the findings of this experiment. 
The larvae started feeding before completion of yolk sac absorption. The same phenomena of starting external feeding keeping apart of internal food in the yolk sac were reported by Das [1995] for Carassius auratus larvae. The timing of starting first feeding have evolutionary values and depends on the availability of the natural food. The synchronized activity of dependable community in nature is important. The rate of larval development of the larvae varied from one species to another. This variation is thought to be temperature dependent, the higher the temperature the quicker were the development [Hoar and Randal, 1969]. The embryonic and larval developments of $B$. gonionotus were studied at an ambient temperature of 27.5 to $30.5^{\circ} \mathrm{C}$. Considering all the facts and findings of the present experiment, the present work provided information's on the early developmental stages of B. gonionotus. Basically the present work generated some information on the early life history, developmental stages and commencement of first feeding time for larval rearing. This study helped to enrich the knowledge of breeding techniques of silver barb at a mobile hatchery level, which may contribute to production of quality fish seed at the farmers' level.

\section{Conclusion}

The present work generated some information on the early life history, developmental stages and commencement of first feeding time for larval rearing. This study would help the hatchery operators in understanding the breeding biology of that fish which may have contribution in further development of aquaculture at farmers' level by transferring of that technology. The knowledge generated from this study could be suggested at the hatchery operator's level through an action research. Thus the productivity of a hatchery could be increased.

\section{Acknowledgements}

The authors are grateful to their honorable teachers Prof. Dr. Mohammad Mahfujul Haque, Prof. Dr. Md. Ruhul Amin and Prof. Dr. Mohammad Harunur Rashid, Bangladesh Agricultural University, Mymensingh, Bangladesh for providing necessary facilities, scholastic guidance, continuous support and encouragement.

\section{References}

[1] Karim, K.A.T.A., S. Dewan and M.G. Hossain. 1988. Length weight relationship and condition factor of Puntius gonionotus (Bleeker). Bangladesh J. Aquaculture, 10: 49-54.

[2] Gupta, M.V. and A. Rab. 1994. Adoption and economics of silver barb (Puntius gonionotus) culture in seasonal waters in Bangladesh. Published by ICLARM, Metro Manila, Philippines, with financial assistance from USAID, Baridhara, Dhaka, Bangladesh

[3] Chakraborty, B.K., M.I. Miah, M.J.A. Mirja and M.A.B. 2006. Habib. Induction of gynogenesis in endangered sarpunti, Puntius sarana (Hamilton) and evidence for female homogamety. Aquaculture; 258: 312-320.

[4] Hussain et al., (eds.) 2008. A guide book on aquaculture technologies. Bangladesh Fisheries Research Institute, Ministry of Fisheries \& Livestock. 96 pp.

[5] Basak, B. 2010. Design and construction of a low cost mobile hatchery: an understanding on technical and economic efficiency. MS Thesis. Department of Aquaculture, Bangladesh Agricultural University, Mymensingh, Bangladesh. 50 pp.

[6] Chakraborty, B.K. 2004. Studies on the artificial propagation, larval rearing and culture of local sarpunti (Puntius sarana). PhD Thesis. Department of Fisheries Management, Bangladesh Agricultural University, Mymensingh. 321 pp.

[7] Karim, M.R. 2009. Embryonic and larval development of climbing perch (Anabas testudineus) bred in captivity. MS Thesis. Department of Fisheries Management, Bangladesh Agricultural University, Mymensingh. 57 pp.

[8] Chakraborty, R.D. and D.S. Murty. 1972. Life history of Indian major carps Cirrhinus Mrigala (Hamilton), Catla catla (Hamilton) and Labeo rohita (Hamilton). J. Inland Fish. Soc., India, 4: 132-161.

[9] Mookerjee, H.K. 1945 Life history of some major carps of Bengal. Sci. Cult., 10 (9): 400-402.

[10] Galman, O.R. and R.R. Avtalion. 1989. Further study of the embryonic development of Oreochromis niloticus (Cichidae, Teleostei) using scanning electron microscopy. J. Fish. Biol., 1989; 34: 653-664.

[11] Jhingran, V.G. 1983. Fish and Fisheries of India. Hindustan Publicating corporation, New Delhi. 666 pp.

[12] Khan, H. 1943. On the breeding habit and development of an Indian carp, Cirrhinus mrigala (Hamilton). Proceedings of the Indian Academy of Science, 18B (1): 1-13.

[13] Das, M. 1995. The energetic of stress tolerance in the early life stages of the gold fish,Carassius auratus L. PhD Thesis. Institute of Aquaculture, University of Stirling, Scotland, UK. 210 pp.

[14] Hoar, W.S. and D.J. Randal. 1969. Fish physiology, Vol. III, Accademic Press, New York, USA, 485 pp. 